\title{
Assessment of Rural Water Supply in Selected Communities in Osun State, Nigeria
}

\author{
David B Olawade ${ }^{1}$, Ojima Z Wada ${ }^{1 *}$, Temitope D Afolalu ${ }^{2}$, Tolu C Oladipo ${ }^{3}$ and Omotayo Asogbon ${ }^{1}$ \\ ${ }^{1}$ Department of Environmental Health Sciences, University of Ibadan, Nigeria
}

${ }^{2}$ Department of Nursing, Afe Babalola University, Nigeria

${ }^{3}$ Department of Medicine and Surgery, Afe Babalola University, Nigeria

Submission: September 09, 2020; Published: September 21, 2020

*Corresponding author: Ojima Z Wada, Department of Environmental Health Sciences, University of Ibadan, Nigeria

\begin{abstract}
The provision of sustainable water supply systems in rural communities in developing countries like Nigeria has been a challenge for several years, thereby promoting the dependency of rural dwellers on polluted surface water sources. This has also promoted water disparities between rural and urban areas, as well as developing and developed countries. In a bid to proffer solutions to this public health challenge, there is need to routinely assess the systems available in our rural communities. This cross-sectional survey assessed the water facilities available in four(4) randomly selected villages across Ayeedade Local Government Area, Osun State. Grab water samples were collected from the main water source in each community and assessed for physico-chemical properties using standard methods. The Sanitary Inspector for the Local Government was also interviewed to obtain insights about the modalities of the water supply system present in the area. All the villages surveyed had at least two handpump boreholes present. All the boreholes were in functional condition. The water facilities in all the communities were constructed in 2011 via collaboration between the Government of Nigeria and UNICEF under the Water Supply and Sanitation Sector Reform Programme (WSSRP)-II. The facilities were routinely maintained by technicians from the Local Government. All the physico-chemical parameters such as nitrate, nitrite chromium, iron and manganese were within the WHO drinking water quality guidelines. However, the $\mathrm{pH}$ across the communities was slightly acidic, with an average of $6.06 \pm 0.08$, while the lead levels exceeded the permissible limits for two(2) of the surveyed communities. The presence of functional water systems in all the villages was meritorious. Perhaps, more commendable because of the Local Government's commitment to routinely maintaining the facilities, this ensured the projects were sustainable. The $\mathrm{pH}$ levels and heavy metal concentrations of the water sources need to be monitored.
\end{abstract}

Keywords: Rural water supply; Water quality; Villages; Disparity; Sustainable water supply

\section{Introduction}

Over the years, the challenge of accessibility and availability of safe water is yet to be curtailed in the nooks and crannies of many nations despite all measures and schemes. Although, studies have shown that there have been drastic improvements overtime. Reports from WHO and UNICEF proves that Nigeria and many sub-Saharan African countries are significantly lagging behind when compared to developing countries with regards to overall accessibility to potable water and basic sanitation services [1,2]. For many rural communities in developing countries, unreliable access to safe drinking water remains a large and growing concern [3].

In sub-Saharan African countries, sustainability of rural water supply systems (WSSs) is an acute problem mainly due to widespread of water infrastructural decay and frequent system breakdowns which inadvertently lead to scarcity of safe water in the region [4]. In Kenya, Tanzania, and Ethiopia, lack of resources and capacity constrains preventive maintenance and exacerbates WSS failures [5]. In Nigeria, during the post-independent era, governments provided water infrastructure and assumed the sole responsibility for water services delivery to the rural population [6]. However, due to the reduced political-will and lack of a sustainable water supply system in place, a significant number of rural communities have been grossly affected [7]. Unfortunately, government and donor agencies have not been able to find a lasting solution to the challenges of poor and unsustainable service delivery in the rural water sector in the country [8].

Ezenwaji et al. [9] recently reported that millions of populaces in the country, particularly in the rural areas, still depended on unimproved drinking water sources such as streams and rivers for their domestic use. The challenge of scarcity of safe water left many water users in rural communities with no other choice but to depend on surface water to meet their water needs [3]. In finding 
sustainable solutions to this challenge, Obeta [10] suggested that in choosing water sources for a rural setting, preference should be given to groundwater sources (wells and boreholes) as surface water sources in Nigeria are extremely polluted and the technologies to treat them are expensive which cannot also be easily sustainable by rural dwellers.

In order to make further recommendations with respect to the provision of sustainable water supply among rural communities in Nigeria, it is essential to evaluate the water supply schemes present in some of these communities. This is why this study was conducted to assess the water supply facilities available among selected villages in Ayeedade Local Government Area (LGA), Osun State

\section{Methodology}

\section{Study location}

The study was carried out at four selected communities at Orile-Owu district located at Ayedaade local government area, Osun state, Nigeria. The Local Government Area (LGA) is bonded to Isokan, Irewole and Aiyedire LGA to the East and Ife North to the West. It consists of over 50 districts and villages.

The selected four communities for the study were; Abimbola village $\left(7^{0} 12^{\prime} 57^{\prime \prime} \mathrm{N} 4^{0} 22^{\prime} 7^{\prime \prime} \mathrm{E}\right)$, Morinlewo village ( $\left.7^{0} 13^{\prime} 9^{\prime \prime} \mathrm{N} 4^{0} 22^{\prime} 35^{\prime \prime} \mathrm{E}\right)$, Origbo village which is also known as Sanuewe $\left(7^{0} 13^{\prime} 23^{\prime \prime} \mathrm{N} 4^{0} 21^{\prime} 54^{\prime \prime} \mathrm{E}\right)$ and Atoba village $\left(7^{0} 13^{\prime} 6^{\prime \prime} N 4^{0} 21^{\prime} 31^{\prime \prime} E\right)$. Figure 1 shows the location of Ayedaade LGA within Osun State.

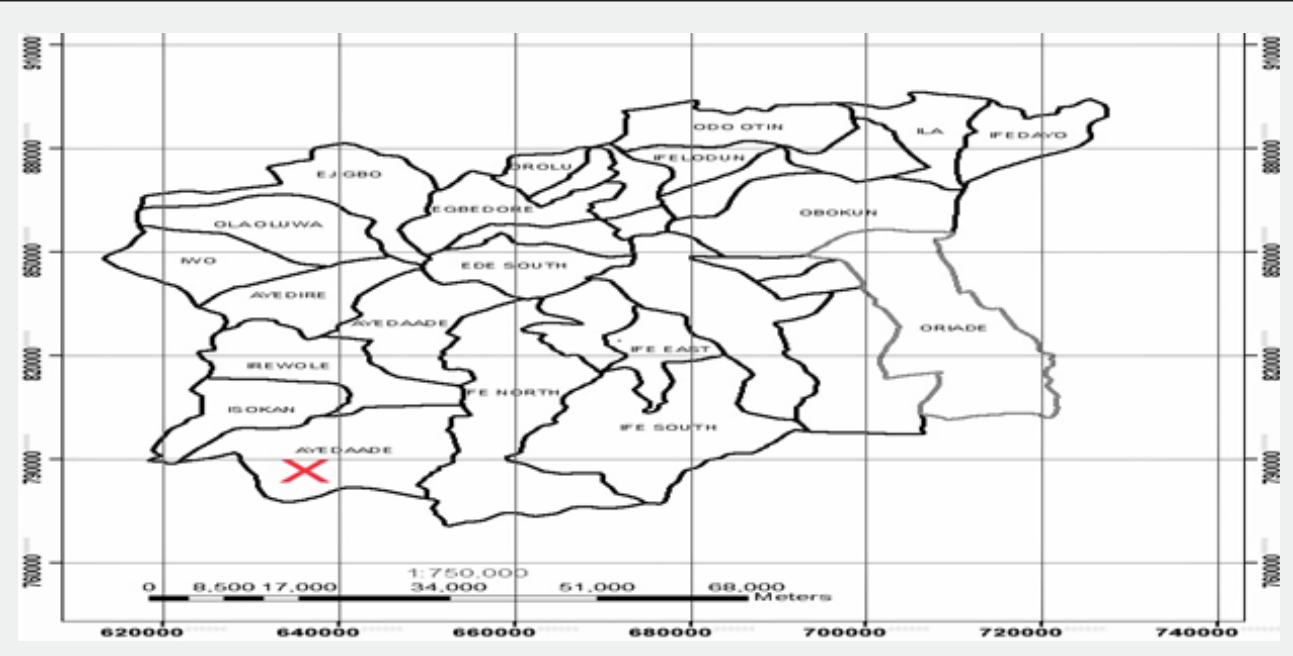

Figure 1: Map Showing Ayedaade LGA marked X [27].

\section{Data collection procedure}

\section{Environmental observation and sanitary inspection}

Each community was assessed for the available water supply available to the villagers. The functionality of the water sources was also verified.

A sanitary survey was done by direct examination of the individual water source to ascertain possible contamination which may affect the water quality with the aid of sanitary inspection forms as structured by WHO [11]. From the sanitary inspection form, the scores were derived in percentage by dividing the number of 'YES' scores by the total number of parameters accessed then multiplied by 100 [12].

\section{Key informant interview guide}

Qualitative data was collected via a key informant interview conducted with the local government sanitation inspector. The data captured includes perception on the water quality, maintenance of the hand-pump boreholes, routine treatment of the water sources and knowledge of past water-related disease outbreaks.

\section{Water sample collection}

Water samples were collected from the most frequently used borehole in each of the selected communities. A total of four (4) water samples were obtained, one from each community. This was done at the early hour of the day (7:00-9:00am). Clean well-drained polyethylene bottles were used to collect the water samples and thereafter taken to the laboratory for analyses. The samples were examined for physico-chemical qualities. Figures 2 to 5 shows each of the boreholes where water samples were obtained.

Physico-chemical parameters like pH, Total Dissolved Solids (T.D.S) and Electrical Conductivity (E.C) were determined by probe method using standard calibrated meter. Total hardness, calcium hardness, magnesium hardness, chloride, and total alkalinity were determined by titrimetric method as prescribed by American Public Health Association [13]. Other physicochemical parameters like nitrate, sulphate, iron, manganese, lead were determined by spectrophotometric method. 


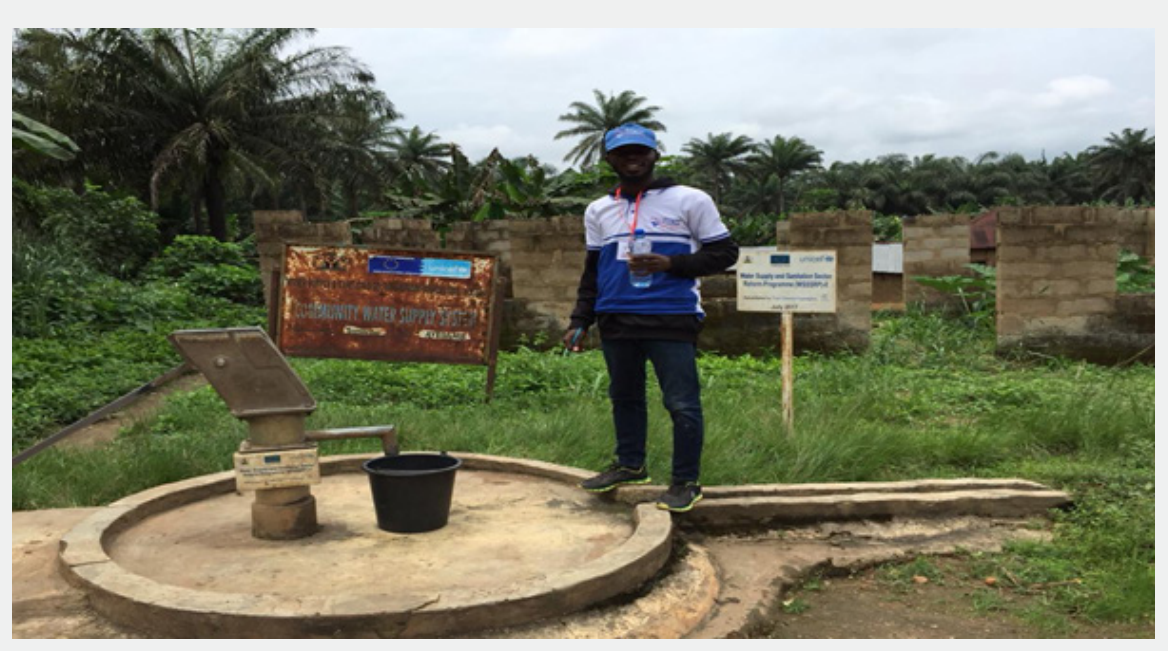

Figure 2: Water facility at Origbo (Sanuewe) village.

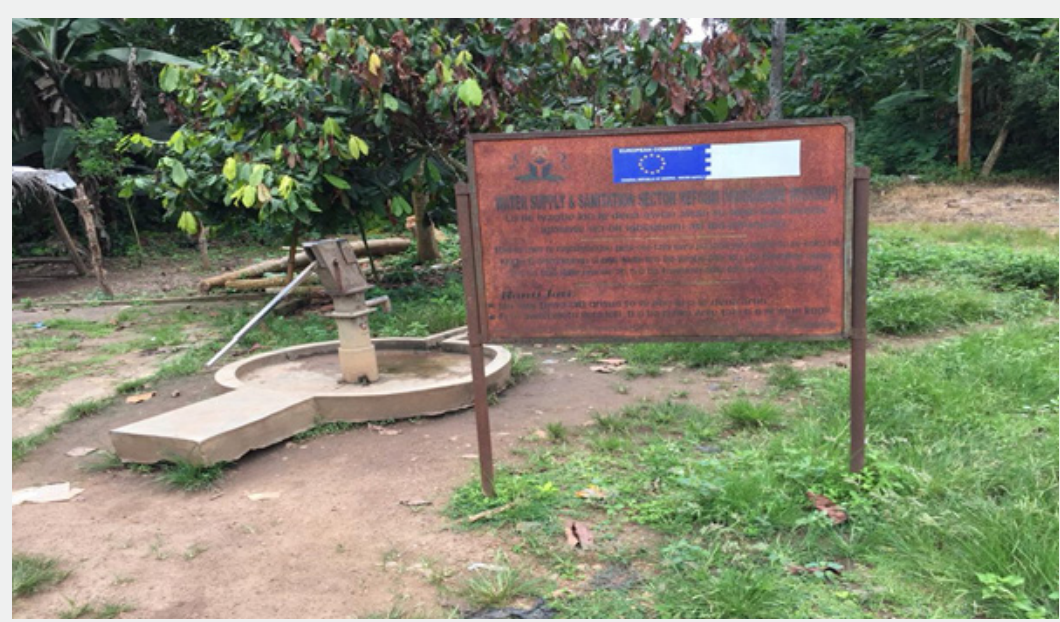

Figure 3: Water facility at Atoba village.

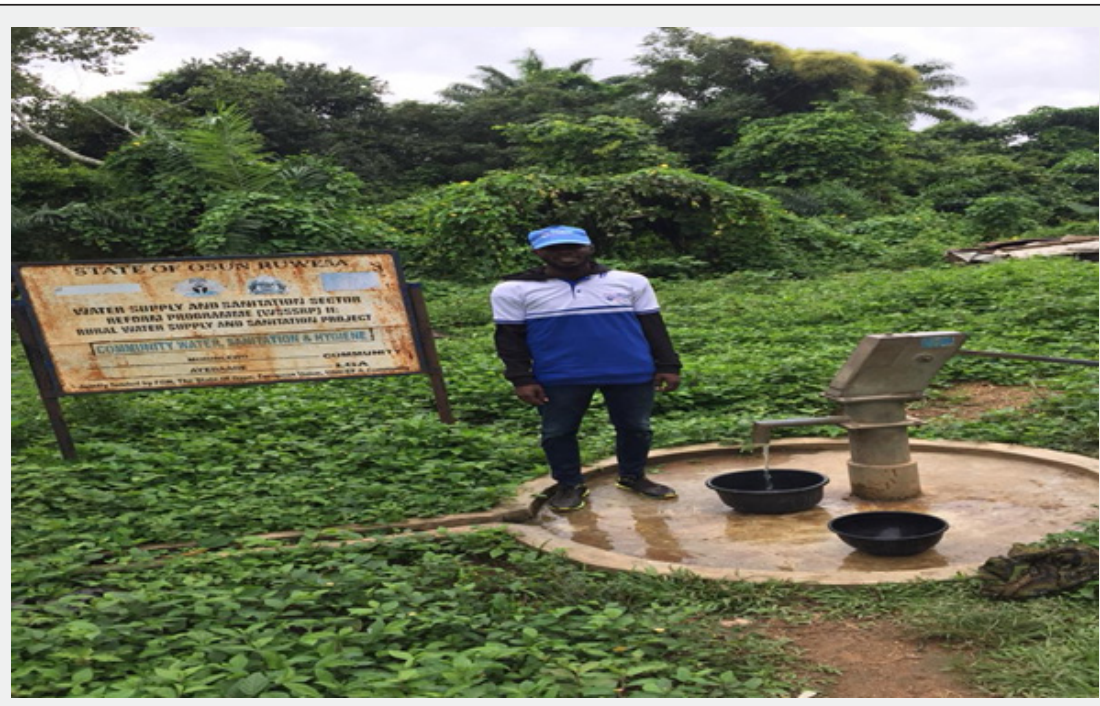

Figure 4: Water facility at Morinlewo village. 


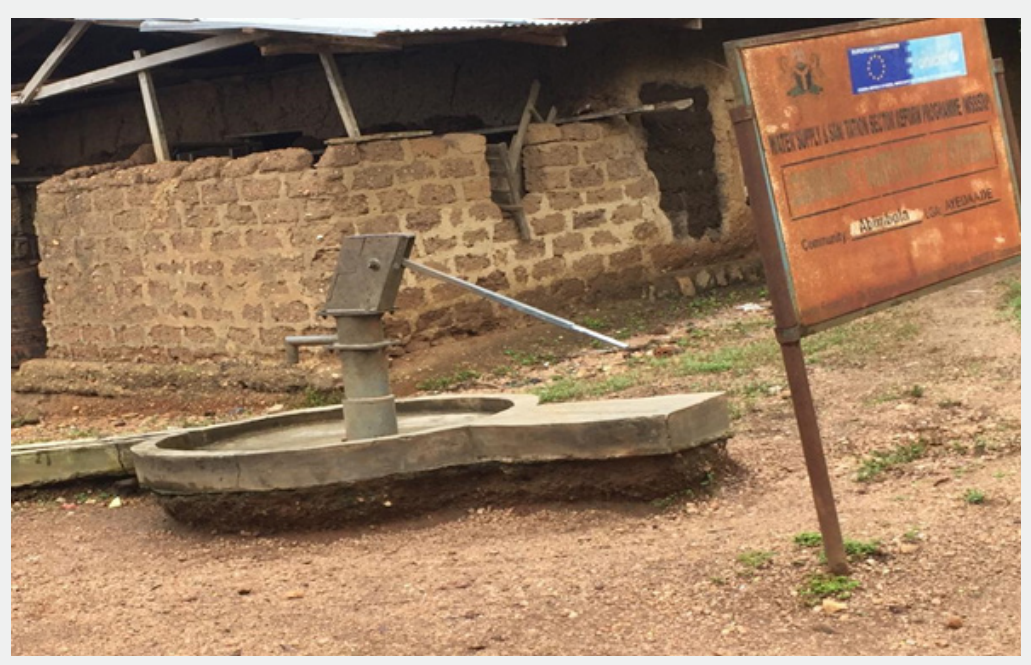

Figure 5: Water facility at Abimbola village.

\section{Results}

\section{Environmental observation}

It was observed that each of the surveyed community across the local government had at least two (2) accessible and functional handpump boreholes. None of the facilities assessed was in an inoperative state.

\section{Sanitary Survey}

From the sanitary survey, the scores of the water facilities showed that Abimbola and Origbo village were at low risk, while
Morinlewo and Atoba village were at medium risk. Across the four communities, the sanitary survey scores in percentages for the water facilities ranged from $60-80 \%$ based on the parameters assessed. Water facilities at Abimbola and Origbo had 80\% each which was the best sanitary percentage score among the selected communities while Morinlewo and Atoba village had the least percentage score of $60 \%$ each. This suggests that Abimbola and Origbo village water facilities are in better sanitary condition when compared with Morinlewo and Atoba village. Details of the risk assessment information and overall percentages are presented in Table 1.

Table 1: The sanitary percentages in the four villages.

\begin{tabular}{|c|c|c|c|c|}
\hline Risk Assessment Information & Abimbola & Origbo & Morinlewo & Atoba \\
\hline Is there a latrine within $10 \mathrm{~m}$ of the borehole & No & No & No & No \\
\hline Is there a latrine uphill of the borehole? & No & No & No & No \\
\hline Are there any other sources of pollution within $10 \mathrm{~m}$ of borehole? & Yes & Yes & Yes & Yes \\
\hline Is the drainage faulty allowing ponding within $2 \mathrm{~m}$ of the borehole? & No & No & No & Yes \\
\hline Is the drainage channel cracked, broken or need cleaning? & No & No & Yes & Yes \\
\hline Is the fence missing or faulty? & Yes & Yes & Yes & Yes \\
\hline Is the apron less than $1 \mathrm{~m}$ in radius? & No & No & No & No \\
\hline Does spilt water collect in the apron area? & No & No & Yes & No \\
\hline Is the apron cracked or damaged? & No & No & No & No \\
\hline Is the handpump loose at the point of attachment to apron? & No & No & No & No \\
\hline Total Score (\%) & $80 \%$ & $80 \%$ & $60 \%$ & $60 \%$ \\
\hline
\end{tabular}

Key informant interview with the local government sanitary inspector on water supply management

Details about the water facilities across the local government area were obtained from the interview with the focal person, who was the Sanitation Inspector for the local government. Having been the Sanitation Inspector for about 12 years, he provided information ranging from history of water supply management and maintenance practices. 
It was revealed that the boreholes across the communities in the local government were constructed in 2011 by collaboration between the Government of Nigeria and UNICEF under the Water Supply and Sanitation Sector Reform Programme (WSSRP)-II which was boldly displayed on the billboards behind every pump. The facilities were subsequently rehabilitated in July 2017 by Tulsi Chanrai Foundation.

Prior to the construction of the facilities, the communities had experienced outbreaks of water borne diseases such as guinea worm disease and cholera when the source of drinking water was solely surface water source from the rivers present in the communities.

Furthermore, it was also reported that a monthly routine inspection, maintenance and servicing of the handpump had been observed over time by representatives from the local government under the hospice of the State Ministry of Environment. Routine water treatment which involved the use of chlorine powder as well as water quality analyses were also routinely conducted by the representatives from the local government.

\section{Drinking water quality analysis}

Tables 2 \& 3 provide details of the water quality results. The temperatures of water for three out of the four villages were similar $\left(25.2^{\circ} \mathrm{C}\right)$, Morintewo village had a slightly lower temperature of $24.6^{\circ} \mathrm{C}$. The $\mathrm{pH}$ of the water samples was all below the WHO permissible limit. The T.D.S of Origbo and Morintewo villages were about twice higher than that of Atoba and Abimbola villages. In comparison to the WHO standards, they were all much lower than the permissible limit. Furthermore, the total hardness levels across the four (4) villages were lower than the WHO permissible limits. The nitrate and nitrite levels in all the water samples were also within permissible limits indicating absence of ongoing faecal contamination. All the other parameters were also within permissible limits, excluding the lead levels in both Morintewo and Abimbola villages.

Table 2: The physicochemical parameters of borehole water sample analyzed from Origbo, Atoba, Morintewo and Abimbola villages.

\begin{tabular}{|c|c|c|c|c|}
\hline Parameters & Origbo & Atoba & Morintewo & Abimbola \\
\hline Temperature $\left({ }^{\circ} \mathrm{C}\right)$ & 25.2 & 25.2 & 24.6 & 25.2 \\
\hline $\mathrm{pH}$ & 6.012 & 6.145 & 6.102 & 5.961 \\
\hline T.D.S(mg/L ) & 186.3 & 76 & 187.25 & 74.95 \\
\hline E.C $(\mu \mathrm{S} / \mathrm{cm})$ & 372.6 & 152 & 374.5 & 149.9 \\
\hline Total Hardness (mg/L) & 108.692 & 154.588 & 96.618 & 41.0623 \\
\hline Calcium hardness(mg/L) & 91.532 & 120.654 & 72.423 & 32.152 \\
\hline Magnesium Hardness (mg/L) & 17.16 & 33.934 & 24.195 & 8.911 \\
\hline Calcium ions (mg/L) & 36.6128 & 48.2616 & 28.9692 & 12.8608 \\
\hline Magnesium ion $(\mathrm{mg} / \mathrm{L})$ & 4.2019 & 8.2917 & 5.908 & 2.1774 \\
\hline Chloride (mg/L) & 99.7 & 124.6 & 99.7 & 99.7 \\
\hline Nitrate (mg/L) & 0.003 & 0.004 & 0.237 & 0.159 \\
\hline Nitrite $(\mathrm{mg} / \mathrm{L})$ & 0 & 0.001 & 0.199 & 0.159 \\
\hline Sulphate(mg/L ) & 0.002 & 0.002 & 0.056 & 0.037 \\
\hline Total Alkalinity (mg/L) & 112.5 & 55.5 & 125 & 86.3 \\
\hline Chromium (mg/L) & 0.0003 & 0.0001 & 0.004 & 0.005 \\
\hline Lead $(\mathrm{mg} / \mathrm{L})$ & 0.001 & 0.001 & 0.22 & 0.166 \\
\hline $\operatorname{Iron}(\mathrm{mg} / \mathrm{L})$ & 0.003 & 0.012 & 0.251 & 0.251 \\
\hline Manganese (mg/L) & 0.004 & 0.004 & 0.191 & 0.197 \\
\hline
\end{tabular}

Table 3: The mean and standard deviation of the parameters from Origbo, Atoba, Morintewo and Abimbola villages in comparism to the WHO limits.

\begin{tabular}{|c|c|c|}
\hline Parameters & Mean ( \pm SD) & Who Limits \\
\hline Temperature $\left({ }^{\circ} \mathrm{C}\right)$ & $25.1 \pm 0.07$ & $6.5-8.5$ \\
\hline $\mathrm{pH}$ & $6.06 \pm 0.08$ & 500 \\
\hline T.D.S $(\mathrm{mg} / \mathrm{L})$ & $131.13 \pm 64.26$ & 1000 \\
\hline E.C $(\mu \mathrm{S} / \mathrm{cm})$ & $262.25 \pm 128.52$ & 500 \\
\hline Total Hardness $(\mathrm{mg} / \mathrm{L})$ & $100.24 \pm 46.69$ & \\
\hline
\end{tabular}




\section{International Journal of Environmental Sciences \& Natural Resources}

\begin{tabular}{|c|c|c|}
\hline Calcium hardness(mg/L) & $79.19 \pm 37.10$ & 200 \\
\hline Magnesium Hardness(mg/L) & $21.05 \pm 10.62$ & 100 \\
\hline Calcium ions(mg/L) & $31.68 \pm 14.84$ & 200 \\
\hline Magnesium ion(mg/L) & $5.14 \pm 2.59$ & 100 \\
\hline Chloride(mg/L) & $105.93 \pm 12.46$ & 250 \\
\hline Nitrate(mg/L) & $0.10 \pm 0.12$ & 30 \\
\hline Nitrite(mg/L) & $0.09 \pm 0.10$ & 250 \\
\hline Sulphate (mg/L) & $0.02 \pm 0.03$ & 200 \\
\hline Total Alkalinity(mg/L) & $94.81 \pm 30.78$ & 0.05 \\
\hline Chromium (mg/L) & $0.00 \pm 0.00$ & 0.01 \\
\hline Lead(mg/L) & $0.10 \pm 0.11$ & 0.3 \\
\hline Iron(mg/L) & $0.13 \pm 0.14$ & 0.1 \\
\hline
\end{tabular}

\section{Discussion}

This study proved otherwise when compared to a report by Adeleye et al. [5], which accounted that in Nigeria, majority of the rural water facilities had collapsed and that most rural dwellers were facing serious and persistent challenges in meeting their water needs, thereby leaving many rural water users with only streams and rivers as water sources. Moreover, the presence of functional hand-pump boreholes in the Four (4) communities was contrary to a study by Adeoye et al. [14] among villages in Kwara State- the villagers majorly depended on streams and shallow wells as their main water sources. The availability of at least two functional boreholes in each community observed from this survey was also in contrast to other studies. A study carried out in some selected communities in Oyo state (Oke-Ogun area) revealed that many of the hand-pumps were not functional and were at the state of disrepairs due to the poor maintenance culture practiced [15]. The availability of local technicians to maintain the water facilities suggests that handpump boreholes do not require foreign expertise for routine maintenance, which makes this facility more sustainable and locally appropriate.

Furthermore, all the sanitary inspection scores from this study are above $50 \%$ as they ranged from $60 \%$ to $80 \%$. This is very similar to the sanitary survey by Abdulsalam \& Sule [16] carried out in two rural communities in Kwara state, Nigeria- upon assessing the six (6) boreholes present, the sanitary scores ranged from $60 \%$ to $100 \%$. The sanitary inspection revealed that all the boreholes had potential sources of pollution within 10 meters from the pumps and also revealed that all the facilities were not fenced. In Morintewo and Atoba communities, the drainage channels of the water facilities were cracked, thereby needing repairs. Also, Atoba community water facility had drainage ponding at about 2 meters from the borehole pump while Morintewo water facility had spilt water collected around the apron area.

The average $\mathrm{pH}$ from this study is similar to that of a survey among communities in Kwara State, Nigeria which revealed the groundwater samples from the 9 boreholes assessed were also acidic (5.72 \pm 0.00$)$ [7]. Water sources with $\mathrm{pH}$ values lesser than 6.5 have been reported to lead to gastrointestinal irritation $[18,19]$. The TDS from the four communities ranged from 74.95 to $187.25 \mathrm{mg} / \mathrm{L}$ which is within the permissible limit of WHO limit of below $500 \mathrm{mg} / \mathrm{L}$. This is contrary to a study done in some communities in Abuja Nigeria where the TDS values ranged from $4 \mathrm{mg} / \mathrm{L}$ to $9100 \mathrm{mg} / \mathrm{L}$ across the communities [20]. The mean Ca concentrations of $31.68 \pm 14.84$ was much higher compared to $3.67 \mathrm{mg} / \mathrm{L}$ reported by Sojobi [17] in a study in Kwara and $2.97 \mathrm{mg} / \mathrm{L}$ reported by Nwankwoala et al. [21] for Yenagoa, Bayelsa state. The mean sulphate concentrations obtained in this survey was found to be lower compared to the range of 12$36.3 \mathrm{mg} / \mathrm{L}$ with mean of $20.4 \mathrm{mg} / \mathrm{L}$ obtained from groundwater samples located in Mararaba-mubi, Northeast of Nigeria [22].

The detection lead concentrations beyond the WHO permissible limit in Morintewo and Abimbola villages were similar to findings in researches conducted in Southern Nigeria and in Abuja, Nigeria- lead concentration in water samples ranged between $0.24-0.34 \mathrm{mg} / \mathrm{L}$ and $0.03-0.3 \mathrm{mg} / \mathrm{L}$ respectively $[20,23]$. High concentration of lead has dangerous effects ranging from hearing loss, growth retardation, and learning disabilities to convulsion, organ failure, coma, and even death [19]. other effects include; tiredness, abdominal discomfort, and anemia [24]. The cause of increased lead concentration in Morintewo and Abimbola water samples would require further investigation. However, the possible causes could be from lead containing agricultural fertilizers contaminating the groundwater [25]. Another possible explanation could be from natural conditions in the aquifers [26].

\section{Conclusion}

The results from this study are quite contrary to several other rural water supply surveys, where the limitation in accessibility to potable water was prominent due to absence of water supply systems or the lack of maintenance of available water facilities. The presence of well-maintained water facilities in the study area 
was quite commendable which is traceable to post-construction support via routine maintenance by concerned agencies. Majority of the physicochemical parameters of water samples tested alongside the sanitary risk assessment are within normal limits making the water quite safe for domestic use. The $\mathrm{pH}$ and lead concentration levels need to be monitored over time in order to ensure the rural dwellers are not exposed to any harm.

\section{References}

1. Ohwo O, Abotutu A (2014) Access to potable water supply in Nigerian cities: Evidence from Yenogoa metropolis. Amer J Water Res 2(2): 3136.

2. World Health Organization (WHO), United Nations International Children's Fund (UNICEF) (2015) Progress on Drinking Water and Sanitation 2010.

3. Eva WM (2015) Comparative Study of Urban and Rural Operation and Maintenance Practice of Water Distribution Systems at Kai Canb Municipality, MSc Thesis, Department of Civil Engineering, University of Cape Town.

4. Adeleye B, Madayese S, Akelola O (2014) Problems of Water Supply and Sanitation, Federal University of Technology, Minna.

5. Carlsson B, Van Dyk G, Esterhuyse C, Meiring G (2010) O \& M Handbook for Water Supply Services - Water Resources in the Northern Cape, Kimberley, South Africa: Department of Housing \& Local Government - Northern Cape, Department of Water Affairs \& Forestry - Northern Cape and Swedish Institute of Public Administration (SIPU) International, 2010.

6. MacDonald AM, Davies J, Calow RC, Chilton JP (2005) Developing Groundwater: A Guide for Rural Water Supply, ITDG Publishing, Rugby, UK.

7. Van Rooijen DJ, Biggs TW, Smout I, Drechsel P (2007) Urban Growth, Wastewater Production and Use in Irrigated Agriculture: a Comparative Study of Accra, Addis Ababa and Hyderabad. Irrigation Drainage Systems 24: 53-64.

8. Allaire M (2009) Drought Mitigation in Semi-Arid Africa: The Potential of Small-Scale Groundwater Irrigation, Projects for sustainable development, CRC Press/Balkema, Leiden, The Netherlands.

9. Ezenwaji EE, Eduputa BM, Okoye IO (2016) Investigation into the Residential Water Demand and Supply in Enugu Metropolitan Area. American Journal of Water Resources 4(1): 22-29.

10. Obeta MC (2018) Rural water supply in Nigeria: policy gaps and future directions. Water Policy 20(3): 597-616.

11. World Health Organization (WHO) (2013) Progress on Drinking Water and Sanitation 2012 update, New York.

12. Sule IO, Agbabiaka TO, Akomolafe AV (2011) Bacteriological Qualities of Water Stored Exteriorly in Storage Tanks. Research Journals of Environmental Science 5(6): 603-610.
13. American Public Health Association (APHA) (2013) Standard Methods for the Examination of Water and Waste water, New York.

14. Adeoye PA, Adeolo AR, Ibrahim HM (2013) Appraisal of Rural Water Supply: Case Study of Kwara State, North Central Nigeria, International Journal of Basic and Applied Science 1(4): 816-826.

15. Toyobo AE, Tanimowo NB (2011) Evaluation of Rural Water Supply Schemes in Selected Communities in Oke-Ogun Area, Oyo State, Nigeria, Global Journal of Science Frontier Research Volume 11 Issue 9 Version 1.0 December 2011 Type: Double Blind Peer Reviewed International Research Journal Publisher: Global Journals Inc.

16. Abdulsalam ZB, Sule IO (2020) Assessment of the Portability of Water Sources in some Rural Communities in Ilorin East, Kwara, Nigeria. Science World Journal 15(1).

17. Sojobi AO (2016) Evaluation of groundwater quality in a rural community in North Central of Nigeria, Environmental Monitoring and Assessment. Environ Monit Assess 188(3): 192.

18. Akhtar MM, Tang Z, Mohamadi B (2014) Contamination Potential Assessment of Potable Ground water in Lahore. Polish Journal of Environmental Studies 23(6): 1095-1916.

19. Khan S, Shahnaz M, Jehai N, Rehman S, Shah MT, et al. (2013) Drinking water quality and human health risk in Charsadda district, Pakistan. Journal of Cleaner Production 60: 93-101.

20. Jibrin NA, Mairami FM, Husseini HU (2015) Assessment of Groundwater Quality in Some Rural Areas of The Federal Capital Territory, Abuja, Nigeria. International Journal of Scientific Research and Education.

21. Nwankwoala HO, Amadi AN, Oborie E, Ushie FA (2014) Hydrochemical factors and correlation analysis in groundwater quality in Yenagoa, Bayelsa State, Nigeria, Applied Ecology and Environmental Sciences 2(4): 100-105.

22. Ishaku JM, Kaigama U, Onyeka NR (21 Assessment of groundwater quality using factor analysis in Mararaba-mubi area, Northeastern Nigeria. Journal of Earth Sciences and Geotechnical Engineering 1(1): 9-33.

23. Adekunle IM, Adetunji MT, Gbadebo AM, Banjoko OB (2007) Assessment of Groundwater Quality in a Typical Rural Settlement in Southwest Nigeria. Int J Environ Res Public Health 4(4): 307-318.

24. Gerlach RF, Cury JA, Krug FJ, Kine SR (2002) Effect of Lead on Dental Enamel Formation. Toxicology 175(1-3): 27-34.

25. Olade MA (1987) Heavy metal pollution and the need for monitoring: Illustration for developing countries in West Africa, In: Huchinson TC, Meema KM (Eds.), Lead, mercury, cadmium and arsenic in the environment, Wiley, New York, pp. 335-341.

26. Bradl H (2005) Heavy Metals in the Environment: Origin, Interaction and Remediation. In: Heike Bradl (Ed.), Volume 6, London, p. 282.

27. Osun State Ministry of Land and Physical Planning and Urban Development (2012) Osun State Secretariat Osogbo, Osun State. 
Your next submission with Juniper Publishers will reach you the below assets

- Quality Editorial service

- Swift Peer Review

- Reprints availability

- E-prints Service

- Manuscript Podcast for convenient understanding

- Global attainment for your research

- Manuscript accessibility in different formats ( Pdf, E-pub, Full Text, Audio)

- Unceasing customer service

Track the below URL for one-step submission https://juniperpublishers.com/online-submission.php 